\title{
Mauricio Swadesh and the beginnings of linguistic anthropology in Mexico
}

\begin{abstract}
In this paper, my purpose is to outline the historical background of linguistic anthropology in Mexico, more specifically, the beginnings of the work carried out by Mauricio Swadesh. As is well known, Swadesh was the initiator of a current of work in Mexico that, although we could characterize it as "linguistic anthropology" it actually addressed many other related aspects (ethnology, history and even prehistory) as evidenced by his numerous investigations, and in two of his most well-known works: La nueva filología y El lenguaje y la vida humane ('The new philology \& Language and human life,' a particularly good example is the chapter dedicated to the so-called "verbal habits"). Moreover, it should be noted that Swadesh taught several generations of linguists in the National School of Anthropology and History (ENAH), many of whom continued with their research work, thus enabling scholars to deal with a whole range of fields in modern-day linguistic anthropology.
\end{abstract}

Volume 3 Issue 4 - 2019

\author{
Luis De La Pena Martinez \\ Department of Press, National School of Anthropology and \\ History, Mexico
}

Correspondence: Luis De La Pena Martinez, Department of Press, National School of Anthropology and History, Mexico, Tel (55) 5666-3454 Tel Email Luis_delapena@inah.gob.mx

Received: May 24, 2019 | Published: July 24, 2019

\section{Mini review}

\section{The philology of the future and the beginnings of linguistic anthropology in Mexico}

In the foreword of the Second edition of La nueva filología (New philology) by Mauricio Swadesh, ${ }^{1}$ published in 1968 by his students, one of them: Daniel Cazés, would refer to what was expressed by Wigberto Jiménez Moreno with regard to Swadesh: “...that it was his presence in Mexico that marked, towards the end of the 1930s, the beginning of linguistic science in our country"; also adding: "...that Swadesh has been the only [Mexico-based] linguist to provide both theoretical and practical contributions to his discipline, and the only one in Mexico to have formed a school of linguistic anthropology, a school which he himself both activated and promoted,". ${ }^{2}$ These three aspects help us to evaluate the work of one of the most important linguists of the 20th Century (disciple and collaborator of Edward Sapir in the famous "school of Yale"), who produced a prolific body of work that contributed to the development of research and teaching, as well as to the dissemination and application of linguistic theory. His work was pioneering, not only in Mexico, since [as noted by Dell Hymes] he was the creator of the "ethnography of speech" or "communication": "Morris Swadesh was an original, productive, provocative linguist. He helped initiate structural linguistics in the United States, and developed practical and scientific linguistics in Mexico. ${ }^{3}$ And speaking of his contributions, Hymes also noted that he: "... had published the first systematic description of an American Indian Language based on phonemic principles (...) and the first systematic American statement of the phonemic method."

Upon his arrival in Mexico, in 1939 (when he came to occupy a professorship of linguistics in the newly created Anthropology Department of the National School of Biological Sciences of the National Polytechnic Institute, antecedent of the ENAH) where he became the Head of the linguistics office of the Autonomous Department of Indigenous Affairs, as well as overseeing the socalled "Tarasco Project," through which the literacy of the indigenous population of that region (Michoacan State) was promoted using their own language. Then, later, in 1941, he published 'The New Philology,' a book published in the "Library of the Teacher", "bound editions," of the Mexican newspaper: El Nacional and Mexico's Secretary of Public Education (SEP). In it, he expounds the theoretical and methodological bases of his thought and his linguistic work, and also projected a renewed and renewing science of language: the philology "of the future," which provided his book with a certain "revolutionary," even "utopian" tone. However, the very title of the book represents an oxymoron (apparently contradictory terms appear in conjunction), as when in its initial lines it dialectically states: "The new philology has its roots in the most remote past", ${ }^{4}$ with that statement Swadesh linked the oldest reflections on language with both modern and contemporary philology and linguistics. In the said work, Swadesh highlights the practical and social nature of linguistic knowledge: "Science is not for the satisfaction of the individual scientist nor to entertain intellectuals (...). While there are social problems in the world, scientists who have the possibility of solving them have no choice but to face their responsibility. Linguists must direct their studies toward solving the problems of social communication in the world" .4 The aim was to present the idea -of teaching linguistics knowledge- through a simple, direct style, aimed at rural teachers and those who had had no preparation in linguistics, in accordance with the postulates of the "socialist education" established by the government of Lázaro Cárdenas. Among its proposals was an orthographic reform of Spanish to facilitate learning and writing, specifically aimed at speakers of an indigenous language, thus promoting the advancement of literacy: "The socialist school will, sooner or later, eliminate the Spanish writing of the ' $h$,' the diagram 'qu,' the 'v' (which sounds the same as the ' $b$ '), and simplify other things further, meaning so much work will be reduced for both students and teachers,". ${ }^{4}$ These educational proposals included the elimination of grammar teaching from primary school, because in this "... all the emphasis has to be made on the clarity of the expression, both oral and written"; 4 which is merely a reflection of Swadesh's attitude towards the study of language and its connection with human life. It was not in vain that one of his best-known books is entitled, precisely, El lenguaje y la vida humana-'Language and human life.'

n the same way, in La nueva filología- The New Philology,' the principles and terminology of the structural analysis of language are already explained concretely: "We can consider the grammatical 
structure from the aspects of form and function, or sense. I do not intend to separate what is essentially inseparable. (...) we have to talk about the form, taking into account its meaning, along with the function, without neglecting the way it is expressed,".4 During World War II, Swadesh returned to the United States and collaborated with the government in the preparation of manuals to learn foreign languages. Later, he would develop his research on the prehistory of languages, using the lexicostatistic glottochronology method, based on lists of vocabulary (one diagnostic and another supplementary) of non-cultural terms, of one hundred words each. Due to his political opinions, Swadesh suffered the pressures and censures during the "McCarthyism" era and decided to return to Mexico in the 1950s, where he found it possible to continue his research and teaching work. Thus, already as a member of the Section of Anthropology of the Institute of Historical Research of the UNAM (which would later become the Institute of Anthropological Research of the same University), and reincorporated into his activity as a professor of the National School of Anthropology and History; as part of the activities of the 58th Annual Meeting of the American Anthropological Association, he published, in 1959: 'Indian linguistic groups of Mexico,' in which he presents his classification of the indigenous languages of the country. In the 1960s, he published works such as Tras la huella linguistic de la prehistoria - 'In search of the linguistic footprint of pre history,' in addition to collaborating with Pedro Bosch Gimpera in his book El problema indoeuropeo -'The Indo-European problem,' in which he proposes "Some correlations between Archeology and Linguistics," and where he explains some of the transformations that took place in the Indo-European languages.

His constant interest in the indigenous languages of Mexico led him to participate, along with several of his students, in the formation of some analytical dictionaries of some indigenous languages (Nahuatl, Purépecha), along with the creation of the 'Seminary of study of Maya writing,' at the Autonomous University of Mexico (UNAM), the antecedent of the current Center for Mayan Studies of the Institute of Philological Research of the UNAM). Also at that time, he traveled to Africa to carry out research on the Mampruli language (in northern Ghana); Swadesh also became one of the first linguists to use the computer, as evidenced by his work at the Computer Center of the UNAM. In 1966, as part of the 'Popular Collection' of the Fondo de Cultura Economic, his work entitled 'Language and human life,' was published, undoubtedly one of the most important books regarding the popularization of linguistic theory in Mexico, and which continues to be reprinted to this day; this was followed, in 1971, with the posthumous publication of what was to become his most important work: 'The Origin and diversification of language,' of which there is still no Spanish translation, and which is referenced by George Steiner in his book entitled 'After Babel.'

\section{The study of verbal customs and the beginning of linguistic anthropology in Mexico}

Specifically, in the publication 'Language and human life, Swadesh included a chapter entitled "Verbal Customs," where he pointed out the following, with regard to the relationship between the customs of a society and the use of language: "The norms of the community indicate who should speak with whom, on what occasions, and what should be said under what circumstances. The rules of the use of words can be called $<<$ verbal habits $>>.^{5}$ This quote anticipates the triple characterization of the rules of discourse proposed by Michel Foucault in 'The order of discourse,' ("taboo of the object," "ritual of circumstance," and "exclusive or privileged right," of the subject speaking) in which it seems to propose a research program that would correspond to what we now recognize as a special discipline: "linguistic anthropology," although in the prologue of his book he confirmed that he was inspired to do so after reading the publication "Ethnography and social linguistics." Thus, he insisted on pointing out that: "The house and the community in which each child is born provide a language, and this is accompanied by many conditions, rules and recommendations, regarding when and with whom the said language should be used, as well as what should be said on each occasion,". ${ }^{6}$ Due to the above, he created a list of rules and requirements that the child must manage in order to communicate better: "... as the child manages to govern the language, they require him to accompany the gestures with the correct words and, as he/she progresses, there are more and more requirements. Approximately, at the age of six, every child should be able to handle the fundamental linguistic rules, including, for example:

1. Say good morning, good afternoon and good night, according to the time of day; or other expressions such as: hello, how are things, how are you, etc.

2. Say goodbye, using some appropriate formula, such as: goodbye, good night, with permission, see you later, until tomorrow (...).

3. Say: health, enjoy your meal, happy New Year, happy birthday.

4. Give thanks for gifts, services, congratulations, etc.

5. Apologize for damages, unplanned accidents, and poorly chosen words.

6. Use names and titles properly, including kinship, respect, etc.

7. Know who to talk to with the formal and informal forms of 'you.'

8. Distinguish between hard and polite words.

9. Discern the issues that should not be dealt with when conversing with older, important, or unknown people.

10. Respect certain situations in which one must speak in a low voice; in which you must keep silent, or in which you must wait for others to speak to you.

11. Accompany the speech with appropriate gestures, such as the handshake, the hug, the inclination of the head or body, etc. Speak normally by looking directly at the people to whom you are speaking; smile or stay serious, depending on the situation; lower ones view,". ${ }^{4}$

Although the previous list is based on mere examples, some from our own culture, it does not prevent the list from being enlarged with references to other situations, such as the child having to learn certain "songs in the round, including their lyrics and tones; rhymes of challenge and mockery, such as eo, eo, te toreo, and the tone that goes with them; the words of the children's game 'tag:' tin marín, dedó pingüé, cúcara mácara, títere fue; cheering and exclamations [related with sports], several tongue twisters; riddles; the prayers and exclamations in the rites, etc. ${ }^{4}$ But he would also note: "In short, the individual acquires not only the language in their phonetics, construction and vocabulary, but also learns a huge amount of customs that limit and formalize the use of words. Such customs fluctuate markedly between different peoples " .7 In this way, Swadesh was responsible in this chapter for analyzing and commenting on some of the issues already mentioned, 
such as the social treatment of people, and the use of titles or special terms, among which the use of social deixis stands out (the use of "you" in both its formal and informal forms), the terms of kinship, or the "affectionate" forms. On the latter subject, the examination of the phonetic rules derived from them attracts the attention (for example: the substitution of/ $\mathrm{r} / \mathrm{or} / \mathrm{l} / \mathrm{and} / \mathrm{s} /$ for/ch/as in "Lencho" for Lorenzo and "Concha" for Concepción). Likewise, Swadesh would address the use of language regarding the rules of courtesy more closely, a topic that has gained interest in linguistic and intercultural pragmatics, including the "courtesy strategies" studied by Levinson and Brown, and the "Principle of courtesy," formulated by Leech, as well as touching on the subjects of "verbal magic," and "verbal taboo" (subjects that were certainly examined by Roman Jakobson in his essay: "The charm of sounds in speech," from his book "The form of sound in language," that refer, in a certain way, to the chapter entitled "The Argonauts of the Pacific," that Malinowsky entitled "The power of words in magic"). In all the above, Swadesh would avail himself of suggestive examples, some of which were taken from his research experience working with the people of Nootka (on the island adjacent to Vancouver Island, in British Columbia, Canada), where he worked alongside Sapir. Swadesh would also pay attention, as already mentioned, to the specialist fields that we would come to refer to as "ethnopoetics" or "ethno literature," where the cultural manifestations such as singing, story telling, proverbs and riddles would fit; fields that today have gained increased importance due to the problems associated with linguistic revitalization, as well as the documentation of languages at risk of disappearing. However, this research program -introduced by Swadesh in his book- did not inspire many linguists and anthropologists in Mexico, unlike what happened elsewhere with the methodological approach that Dell Hymes called the "ethnography of speech," or the "ethnography of communication," with which this author proposed the study of "communicative competence," as well as that of "communicative events," and which we now recognize, thanks to the famous acrostic: SPEAKING, which is one of the most immediate antecedents of the "Linguistic Anthropology" proposed by Alessandro Duranti, ${ }^{9-11}$ in his book of the same name. This one as one of the four of Anthropology (Biological Anthropology, Cultural and Social Anthropology, Archaeology and Linguistic Anthropology). Perhaps the lack of systematization and an adequate methodology caused these issues to be relegated, meaning more importance was given to other points raised by Swadesh in his work, such as those concerning glottochronology, or the classification of indigenous languages; however, the above examples are sufficient to understand the importance of the contributions of Mauricio Swadesh to the linguistic anthropology in, and from, Mexico. Not to get confused with Anthropological Linguistics which object of study are Mexican and Amerindian indigenous languages. ${ }^{8}$

\section{Conclusion}

The "heteroglottic" period and the penetration of the past by linguistic means, In 1987, on the 20th Anniversary of the death of Mauricio Swadesh, the Institute of Anthropological Research of the UNAM held the First Linguistics Colloquium "Mauricio Swadesh," where I collaborated as an assistant to the Organizing Committee, coordinated by the linguist and anthropologist Daniel Cazés, ${ }^{12}$ and in which another student of Swadesh, Leonardo Manrique Castañeda, also participated, representing the Department of Linguistics of the Instituto Nacional de Antropología e Historian (National Institute of Anthropology and History - INAH). As a result, and in order to mount the exhibition with some documents from Mauricio Swadesh, I was allowed access to his personal file, which was under the stewardship of the children of the teacher Evangelina Arana de Swadesh, who had recently passed away, as well as the linguist Benjamín Pérez. Thus, in an initial review of the archive, I was able to choose [for the aforementioned exhibition] a way of collecting the data concerning the glottochronology of the Amerindian languages; deciding upon some of the 200 word lists of non-cultural vocabulary, plus the results that had been sent to Swadesh by several researchers, as well as a typed table of transformations of the Indo-European languages, including hand-made corrections, along with two mimeographed texts, one of them, undated, entitled "Penetration of the past by linguistic means," which I have as yet been unable to locate in any of the the bibliographies concerning Swadesh's work (which makes me presume that it is an unpublished text), and another entitled "Ways of writing sounds," dated 1965, which was presented at the University of Syracuse.

In the text "Penetration of the past by linguistic means," Swadesh proposes the term "heteroglottic" to define the current period of language history, a term that does not appear in the books where he presents, by means of an analogy with archeology, the periods of the language he calls "eoglottic," "pal eoglottic," and "neo-gothic." The "heteroglottic" period was to be defined by Swadesh as follows:

"The important modern languages today are in the heteroglottic, or mixed language stage, marked by much language mixture, structural diversity within each language, and the use of non-spoken forms, such as writing, mathematics and electronic computers." For all the above reasons, I believe that this text synthesizes the intellectual trajectory of Mauricio Swadesh and gives us the opportunity to initiate a historical review of his work, as well as to value his teaching and research work, along with the impact it had on the development of linguistics in Mexico, especially through the preparation and training of outstanding linguists such as Evangelina Arana, Roberto Escalante, Leonardo Manrique, Juan José Rendón and Daniel Cazés, among others, who studied at the National School of Anthropology and History. Finally, I would like to quote some words from Daniel Cazés, ${ }^{12}$ which he placed at the beginning of his book El pueblo matlazinca de San Francisco Oxtotilpán y su lengua-The matlazinca people of San Francisco Oxtotilpán and their language,' published in 1967, in the Acta Anthropological collection of the Society of Alumni of the ENAH: "The life of Mauricio, as he called us, is part of the life of all of us, his students, to such an extent that it is impossible for us to conceive his absence. We are part of his creation and continue living it. Our memory of Mauricio is currently our greatest stimulus to continue, to the extent of our abilities, the work that he entrusted to us. Our memory is much more than just a memory. It is the way in which his instruction, his demands and his desires are revealed through the work of his disciples and in everything we do henceforth," ${ }^{13,14}$

\section{Acknowledgments}

None.

\section{Conflicts of interest}

The author declares there are no conflicts of interest.

\section{Funding}

None. 


\section{References}

1. Hymes D. Foreword, Morris Swadesh: From the First Yale School to World Prehistory. Morris Swadesh, Word. 1971;26(1):119-138.

2. Swadesh M. Indian linguistic groups of Mexico. Mexico: ENAH-INAH 1959. $14 \mathrm{p}$.

3. Morris Swadesh, Joel Sherzer, Dell H Hymes. The Origin and Diversification of the Language. Chicago: Aldine Atherton; 1971. 350 p.

4. Swadesh Mauricio. Language and human life. Mexico: Fondo de Cultura Economic, Popular Collection No. 83; 1961. 258 p.

5. Samuel Ramos, Nabor Carrillo, Fernando Alba. Supplements of the Seminar on Scientific and Philosophical Problems. Mexico: UNAM; 1960a. 25 p.

6. Some Correlations of Archeology and Linguistics. $2^{\text {nd }}$ Ed. Appendices to The Indo-European Problem by Pedro Bosch Gimpera, UNAM; 1960b. $93 \mathrm{p}$.

7. Aguirre Beltrán G. The Tarasco Project: Mauricio Swadesh in Vernacular Languages. Mexico: Editions of the Chata House; 1983. 36 p.
8. Blench R, Mathew Spriggs. Archeology and Language. Theorical and Methodological Orientations. London and New York: Routledge; 1997. 301 p.

9. Duranti A. Linguistic Anthropology. Madrid: Cambridge University Press; 2000. 185 p.

10. Duranti A. Linguistic Anthropology. Massachusetts: Blackwell Publishers; 2001. 217 p.

11. Duranti A. A companion to linguistic Anthropology. Australia: Blackwell Publishing; 2004. 11 p.

12. Daniel Cazés. This publication contains a bibliography of Mauricio Swadesh. $1^{\text {st }}$ Ed. Biblioteca del Maestro. Mexico: published by the newspaper El Nacional; 1968. 77 p.

13. Cazés D. The matlazinca people of San Francisco Oxtotilpán and their language. Mexico: ENAH, Student Society; 1967. 34 p.

14. Cazés D JJ, Rendón, Sancho M. Mauricio Swadesh (1909-1967) in the magazine Community. Mexico: Universidad Iberoamericana; 1969. 8 p. 